\title{
Ummessaolokauden ruokintatason vaikutus lypsylehmien käyttäytymiseen ja hyvinvointiin
}

\author{
Saana Orkola $^{1)}$, Seija Jaakkola ${ }^{1)}$, Vera Hakala ${ }^{1)}$, Siru Salin $^{1)}$, Matti Pastell ${ }^{1)}$, Laura Hänninen ${ }^{2)}$, Tuomo \\ Kokkonen $^{1)}$ \\ ${ }^{1)}$ Maataloustieteiden laitos, PL 28, 00014 Helsingin yliopisto; etunimi.sukunimi@helsinki.fi \\ ${ }^{2)}$ Kliinisen tuotantoeläinlääketieteen osasto, PL 57, 00014 Helsingin yliopisto; \\ etunimi.sukunimi@helsinki.fi
}

\section{Tiivistelmä}

Ummessa olevien lehmien energian saantia voidaan terveydellisistä syistä joutua rajoittamaan, jolloin rehun syöntiaika ja mahdollisuus syöntikäyttäytymisen toteuttamiseen pienenee. Vähentynyt syöntiaika voi heikentää nautojen hyvinvointia ja lisätä esimerkiksi kielenpyöritystä tai rakenteiden manipulointia. Ravitsemustila saattaa myös vaikuttaa hypotalamus-aivolisäke-lisämunuaisakselin (HPA-akselin) toimintaan.

Tutkimuksessa selvitettiin, miten poikimista edeltävä vapaa tai rajoitettu ruokinta vaikuttaa lehmien käyttäytymiseen sekä glukokortikoidien erittymiseen. Kokeessa oli mukana 16 vähintään toista kertaa poikivaa ay-lehmää. Lehmien käyttäytymistä videoitiin yhden vuorokauden ajan 23 päivää ja 10 päivää ennen odotettua poikimista sekä 14 päivää poikimisen jälkeen. Lehmiltä kerättiin sontanäytteitä kolme kertaa päivässä 24 ja 11 päivää ennen poikimista sekä 12 päivää poikimisen jälkeen. Sontanäytteistä määritettiin kortisolin aineenvaihduntatuotteiden pitoisuudet. Vapaasti ruokitut lehmät $(\mathrm{V})$ saivat viikoilla $6-4$ ennen poikimista säilörehua $150 \%$ (keskiarvo $144 \mathrm{MJ}$ $\mathrm{ME} / \mathrm{pv}$ ) ja rajoitetusti (R) ruokitut $100 \%$ (keskiarvo $95 \mathrm{MJ} \mathrm{ME} / \mathrm{pv}$ ) energiantarpeestaan. Kolme viikkoa ennen odotettua poikimista (tunnutusruokinnan alkaessa) vapaasti ruokitun ryhmän energian saantia alettiin rajoittaa siten, että laskennallinen energian saanti aleni vertailuryhmän tasolle ennustettuun poikimapäivään mennessä. Tunnutusruokintaan sisältyi molemmilla ryhmillä väkirehua $30 \%$ rehuannoksen energiasisällöstä. Poikimisen jälkeen molemmilla ryhmillä oli samanlainen ruokinta siten, että väkirehumäärä nostettiin $11 \mathrm{~kg} / \mathrm{pv}$ :ssä viimeiseen videointiin (14 päivää poikimisen jälkeen) mennessä. Säilörehua annettiin vapaasti.

Runsas säilörehuruokinta lisäsi lehmien säilörehun syömiseen käyttämää aikaa 23 päivää ennen odotettua poikimista (216 vs. $152 \mathrm{~min} / \mathrm{pv}, \mathrm{p}<0,05)$ ja syöntikertojen määrää $(18,4 \mathrm{vs.} 12,0 \mathrm{krt} / \mathrm{pv}$, p<0,01), mutta ei vaikuttanut märehtimisaikaan $(\min / \mathrm{pv})$ tai märehtimisjaksojen määrään $(\mathrm{krt} / \mathrm{pv})$. Ummessaolokauden ruokintatasolla ei ollut vaikutusta lehmien syönti- ja märehtimiskäyttäytymiseen 14 päivää poikimisen jälkeen. Ummessaolokauden ruokintataso ei vaikuttanut makuu- ja seisomisaikoihin 23 päivää ennen odotettua poikimista. Poikimisen jälkeen V-ryhmän lehmien makuuaika oli suuntaa-antavasti pidempi (691 vs. $607 \mathrm{~min} / \mathrm{pv}, \mathrm{p}<0,10)$ ja seisomisaika lyhyempi (749 vs. $832 \mathrm{~min} / \mathrm{pv}, \mathrm{p}<0,10)$ kuin R-ryhmän lehmien.

V-ryhmän lehmillä havaittiin suuntaa antavasti enemmän hoitokäyttäytymiskertoja (nuoleminen tms.) 23 päivää ennen odotettua poikimista ( 150 vs. $112 \mathrm{krt} / \mathrm{pv}, \mathrm{p}<0,10)$. Hoitokäyttäytymisjaksot olivat pidempiä R-ryhmän lehmillä ( 0,34 vs. $0,22 \mathrm{~min} / \mathrm{krt}$, p <0,05). Ruokintataso ei vaikuttanut rakenteiden manipulointiin aikaan 23 päivää ennen odotettua poikimista. V-ryhmän lehmillä havaittiin suuntaa antavasti enemmän rakenteiden manipulointia poikimisen jälkeen $(11,3$ vs. $7,8 \mathrm{~min} / \mathrm{pv}$, $\mathrm{p}<0,10)$. Kielenpyöritystä havaittiin vain muutamilla lehmillä ja niilläkin yksittäisiä, lyhyitä jaksoja. Ummessaolokauden ruokintataso ei vaikuttanut kortisolin aineenvaihduntatuotteiden pitoisuuksiin sontanäytteissä.

Asiasanat: Lypsylehmä, ruokinta, ummessaoloaika, hyvinvointi, käyttäytyminen, HPA-akseli 


\section{Johdanto}

Eläimen hyvinvointi voidaan määritellä yksilön tilana suhteessa ympäristöönsä. Vaikeudet selviytyä ympäristössä ovat merkki heikosta hyvinvoinnista (Broom 1991). Eläimen tilaan vaikuttavat monet tekijät: eläimen tunteet, tarpeet, terveys ja stressitekijät. Stressi voidaan määritellä sellaiseksi ympäristön vaikutukseksi, joka ylirasittaa yksilön säätelyjärjestelmiä ja huonontaa elinkykyä (Broom 2010). Hyvinvointiin voivat vaikuttaa useat ympäristötekijät, kuten tuotanto-olosuhteet, eläinten hoitajat, luontaisten käyttäytymistarpeiden toteuttamismahdollisuudet, terveys sekä rehun ja veden saanti ja niiden laatu (Phillips 2002). Eläinten hyvinvointitutkimuksissa käyttäytyminen on tärkeässä roolissa, sillä se muuttuu, jos eläimellä on vaikeuksia tulla toimeen tietyssä ympäristössä. Käyttäytymisen muutokset voivat helpottaa eläimen sopeutumista ympäristöönsä, mutta joissain tapauksissa tietyt käyttäytymismallit voivat jopa vahingoittaa eläintä (Broom 1991). Naudan etogrammin avulla on mahdollista määritellä erilaisia lajityypillisiä käyttäytymismalleja, joiden avulla eläimen käyttäytymistä voidaan selittää (Martiskainen ym. 2005). Eläinten käyttäytymistä tutkittaessa on otettava huomioon, että käyttäytymiseen vaikuttavat useat eri tekijät. Jotta käyttäytymistä voidaan käyttää hyvinvoinnin mittarina, on osattava erottaa tietyn käyttäytymistoiminnan taustalla olevat motivaatiotekijät ( Broom ja Fraser 2007).

Jos eläimen hyvinvointi heikkenee, sillä voi esiintyä häiriökäyttäytymistä tai erilaisia stereotypioita (Redbo ym. 1996). Stereotyyppinen käyttäytyminen kehittyy yleensä eläimelle epäsuotuisissa tilanteissa ja se on usein yhteydessä turhautumiseen ja virikkeettömään ympäristöön. Stereotypiasta puhuttaessa tarkoitetaan kaavamaisesti toistuvia käyttäytymismalleja, joilla ei ole näkyvää tarkoitusta (Mason ja Rushen 2006). Aikaisemmissa tutkimuksissa on todettu, että rajoitettu ruokinta voi johtaa käyttäytymishäiriöiden, kuten stereotyyppisen suun alueen käyttäytymisen lisääntymiseen lypsylehmillä. Syöntikäyttäytymisen muutokset on kasvavassa määrin hyväksytty käyttökelpoiseksi mittariksi lehmien terveyden tutkimisessa (Keyserlingk ja Weary 2010). Redbo ym. (1996) osoittivat, että naudoilla on tarve syöntikäyttäytymiseen riippumatta pötsin täyteisyydestä. Lehmien syöntikäyttäytyminen on usein synkronisoitua, ja tuoreen rehun jakaminen stimuloi syönnin aloittamista (Keyserlingk ja Weary 2010). Myös rehun koostumus vaikuttaa syöntiaikaan (Phillips 2000). Nielsenin (1999) mukaan rajoitettu ruokinta voi nopeuttaa rehun syöntiaikaa lypsylehmillä. Lypsylehmien energiansaantia rajoitetaan ummessaolokaudella, jolloin niillä on usein vähemmän rehua saatavilla kuin lypsykaudella.

Stressi on yksi potentiaalisista hyvinvoinnin mittareista, mutta sille ei ole vakiomääritelmää (Hofer ja East 1998, ref. Möstl ja Palme 2002). Useimmiten stressi määritellään ympäristötekijänä, stressorina, joka aiheuttaa elimistön homeostasian epätasapainon. Stressi aiheuttaa HPA-akselin (hypotalamus-aivolisäke-lisämunuaiskuoriakseli) aktivoitumisen, mikä lisää ACTH:n (adrenokortikotropiini) vapautumista aivolisäkkeen etulohkosta. Tämä puolestaan nostaa veren glukokortikoiditasoja. Lyhytaikaisen stressin aikana glukokortikoidit parantavat eläimen elinkykyä ja mahdollisesti vaikuttavat eläimen käyttäytymiseen (Korte ym. 1993). Jos HPA-aktiivisuus on pitkään koholla, sen on todettu olevan eläimelle haitallista (Moberg ja Mench 2000, ref. Morrows ym. 2002). Tällöin puhutaan kroonisesta stressistä. Tutkimusten mukaan ruokinta ja eläimen kiihtyminen voivat aiheuttaa muutoksia märehtijöiden HPA-akselin toiminnassa (Munksgaard ym. 2006). Stressiä on arvioitu mittaamalla veren kortisolipitoisuuksia (Broom ja Johnson 1993). Kortisolipitoisuuden mittaaminen verestä edellyttää toistuvaa verinäytteiden ottoa ja eläimen käsittelyä, mikä voi vaikuttaa eläimen stressitasoon. Kortisolitasot myös vaihtelevat kortisolin luonnollisen vuorokausirytmin takia. Naudoille on kehitetty stressin arviointiin menetelmä, jossa kortisolin aineenvaihduntatuotteiden (kortisolimetaboliittien) mittaus tehdään sonnasta (Morrow ym. 2002, Möstl ja Palme, 2002). Haitalliset olosuhteet nostavat sonnan kortisolimetaboliittipitoisuutta (Möstl ja Palme, 2002). Myös rehunsyönti voi vaikuttaa sonnan steroiditasoihin.

Tämän tutkimuksen tarkoituksena oli selvittää, miten ummessaolokauden vapaa tai rajoitettu ruokinta vaikuttaa lypsylehmien käyttäytymiseen ja aikabudjettiin. Tarkoituksena oli havainnoida erityisesti mahdollisia muutoksia lehmien syöntikäyttäytymisessä ja hypoteesina oli, että ummessaolokauden rajoitettu ruokinta lisää käyttäytymishäiriöitä tai stereotypioita lypsylehmillä. Sonnan kortisoliaineenvaihduntatuotteiden määrityksen hypoteesi oli, että rajoitettu ruokinta aiheuttaa muutoksia lehmien HPA-akselin toiminnassa. Lisäksi pyrittiin selvittämään, onko kortisoliaineenvaihduntatuotteiden erittymisessä havaittavissa vuorokausivaihtelua. 


\section{Aineisto ja menetelmät}

Tutkimus tehtiin Helsingin yliopiston Maataloustieteiden laitoksen ja Kliinisen tuotantoeläinlääketieteen laitoksen yhteistyönä. Koe oli osa projektia, jossa tutkittiin lypsylehmien metabolisen stressin hallintaa poikimisen yhteydessä. Koe tehtiin Helsingin yliopiston Viikin opetusja tutkimustilan navetassa 10.9.2009- 1.4.2010. Kokeessa oli mukana 16 vähintään kerran poikinutta ayrshire- rotuista lypsylehmää. Koe oli jatkuvan koemallin mukainen täydellisesti satunnaistettu lohkokoe, jossa oli kaksi koekäsittelyä. Lehmät jaettiin odotetun poikimapäivän ja -kerran mukaan kahdeksaan kahden lehmän pariin. Parin toinen lehmä arvottiin koe- ja toinen vertailuryhmään. Koe alkoi jokaisen lehmän kohdalla kuusi viikkoa ennen odotettua poikimapäivää ja päättyi kahdeksan viikkoa poikimisen jälkeen. Kokeen alkaessa lehmät olivat ummessa.

Lehmiä pidettiin parressa kaulastaan kytkettynä ummessaolokauden ja kahden ensimmäisen tuotosviikon ajan. Kolmella ensimmäisellä koeviikolla vertailuryhmän (R) lehmät saivat säilörehua rajoitetusti, $100 \%$ (keskimäärin 95 MJ ME/pv) energiantarpeestaan. Koeryhmän (V) lehmät puolestaan saivat säilörehua $150 \%$ (keskimäärin $144 \mathrm{MJ} \mathrm{ME} / \mathrm{pv}$ ) laskettuun energiantarpeeseensa nähden. Lehmien yksilöllinen energiantarve laskettiin voimassa olevien ruokintasuositusten mukaisesti (MTT 2011). Koeryhmän rehuannosta alettiin rajoittaa kolme viikkoa ennen odotettua poikimista siten, että lehmien laskennallinen energiansaanti aleni vertailuryhmän tasolle odotettuun poikimapäivään mennessä. Tunnutusruokinnan aikana, alkaen kolme viikkoa ennen odotettua poikimista, lehmät saivat $30 \%$ energiansaannistaan väkirehusta. Poikimisen jälkeen vertailu- ja koeryhmän ruokinnat olivat samanlaisia: lehmät saivat säilörehua vapaasti ja molemmat ryhmät saivat samalla tavalla väkirehua. Lehmien käyttäytymistä havainnoitiin videoinnilla kaksi kertaa ennen poikimista (-23 pv ja $-10 \mathrm{pv})$ ja kerran poikimisen jälkeen (+14 pv). Videoista rekisteröitiin jatkuvalla havainnolla (Martin ja Bateson 2007) lehmien suuhun ja kehonasentoihin liittyviä käyttäytymistoimintoja Cowlog-ohjelmalla (Hänninen ja Pastell 2009). Videoita koodasi kaksi henkilöä ja sama henkilö katsoi parin molempien lehmien videot. Sontanäytteitä otettiin kolmesti päivässä (klo 6, 14 ja 21) kolme kertaa kokeen aikana (-24 pv, -11 pv ja +12 pv) kortisolimetaboliittien määrittämistä varten. Kortisolimetaboliittien pitoisuus määritettiin aiemmin validoidulla (Morrow ym. 2002) RIA-menetelmällä.

Tilastollista analyysiä varten laskettiin jokaiselle lehmälle tutkittujen käyttäytymistoimintojen kestot vuorokauden aikana, käyttäytymisjaksojen lukumäärät ja jaksojen kestot. Analyysissä selvitettiin ruokintatason vaikutus lehmien syömiskäyttäytymiseen, märehtimiseen ja muuhun suuhun liittyvään käyttäytymiseen sekä muuhun aktiivisuuteen. Tilastolliset testaukset tehtiin varianssianalyysillä käyttäen SAS-ohjelmiston versio 9.1:n Mixed proseduuria (SAS Institute Inc.). Normaalisuustestauksessa käytettiin Shapiro-Wilk- testiä. Tilastollisessa mallissa kiinteänä tekijänä oli ruokinta ja satunnaisena tekijänä pari. Kaikissa taulukoissa tulokset on esitetty LS (Least squared)keskiarvoina. Osassa tuloksia muuttujien residuaalit eivät olleet normaalijakautuneita. Nämä muuttujat analysoitiin uudestaan Friedmanin kaksisuuntaisella ei-parametrisella varianssianalyysilla.

\section{Tulokset ja tulosten tarkastelu}

\section{Syönti-, juonti-ja märehtimiskäyttäytyminen}

23 päivää ennen odotettua poikimista vapaasti $(V)$ ruokitut lehmät söivät keskimäärin pidempään $(\mathrm{p}<0,05)$ ja useammin $(\mathrm{p}<0,01)$ kuin rajoitetusti $(\mathrm{R})$ ruokitut lehmät (taulukko 1). Ryhmien välillä ei ollut eroja syöntikäyttäytymisessä 10 päivää ennen poikimista eikä 14 päivää poikimisen jälkeen. 23 päivää ennen poikimista R-ryhmällä oli enemmän juontijaksoja $(\mathrm{p}<0,10)$ kuin V-ryhmällä ja keskimääräinen juontijakson kesto oli niillä lyhyempi $(\mathrm{p}<0,10)$. Ryhmien välillä ei ollut eroja juontikäyttäytymisessä 10 päivää ennen poikimista eikä 14 päivää poikimisen jälkeen. Märehtimisessä ei ollut tilastollisesti merkitseviä eroja ryhmien välillä 23 päivää ennen poikimista eikä poikimisen jälkeen. 10 päivää ennen poikimista V-ryhmän lehmät märehtivät kauemmin vuorokauden aikana (393 min vs. $317 \mathrm{~min})$ kuin R-ryhmän lehmät $(\mathrm{p}<0,05)$. Niiden märehtimisjaksot olivat myös pidempiä (16,7 min vs. 12,3 min, $\mathrm{p}<0,10)$ kuin R-ryhmällä. Syöntinopeudessa ei ollut eroja ryhmien välillä millään havaintokerralla. 
Taulukko 1. Lehmien keskimääräiset vuorokauden syönti-, vedenjuonti- ja märehtimiskäyttäytyminen sekä rehunsyöntinopeus vuorokauden ajalta 23 päivää ennen odotettua poikimista ( $n$ vertailu $=7, n$ koe $=7$ ).

\begin{tabular}{|c|c|c|c|c|}
\hline \multicolumn{5}{|c|}{$-23 p v$} \\
\hline Käyttäytyminen & Rajoitettu & Vapaa & SEM & $\begin{array}{l}\text { Tilastollinen } \\
\text { merkitsevyys }\end{array}$ \\
\hline Syönti (min) & 152,4 & 216,7 & 13,05 & $*$ \\
\hline Syöntijaksot (krt) ${ }^{a}$ & 21,9 & 33,9 & 2,36 & $* *$ \\
\hline $\begin{array}{l}\text { Syöntijakson kesto } \\
\text { (min/krt) }\end{array}$ & 7,2 & 6,4 & 0,56 & \\
\hline $\begin{array}{l}\text { Syöntinopeus } \\
\text { (g ka/min) }\end{array}$ & 67,2 & 62,4 & 5,38 & \\
\hline Juonti (min) & 11,2 & 7,6 & 1,89 & \\
\hline Juontijaksot (krt) ${ }^{\mathrm{a}}$ & 39,6 & 26,0 & 6,52 & \\
\hline $\begin{array}{l}\text { Juontijakson kesto } \\
\text { (min/krt) }\end{array}$ & 0,28 & 0,35 & 0,034 & $\circ$ \\
\hline Märehtiminen (min) & 460,4 & 505,7 & 27,90 & \\
\hline $\begin{array}{l}\text { Märehtimisjaksot (krt) } \\
\text { Märehtimisjakson }\end{array}$ & 29,1 & 28,3 & 3,03 & \\
\hline $\operatorname{kesto}(\min / \mathrm{krt})^{{ }^{a}}$ & 16,8 & 19,2 & 2,38 & \\
\hline
\end{tabular}

Tilastollinen merkitsevyys: ${ }^{\circ} \mathrm{p}<0,10 ; * \mathrm{p}<0,05 ; * * \mathrm{p}<0,01 ; * * * \mathrm{p}<0,001$

${ }^{\mathrm{a}}=$ Analysoitu Friedmanin varianssianalyysillä

Naudan syöntikäyttäytymiseen vaikuttavat muun muassa rehun määrä ja koostumus sekä tuoreen rehun jako (Nielsen ym. 2000, Phillips 2002, Munksgaard ym. 2005). Syöntijaksojen määrän ja keston on todettu olevan yksilöllisiä (Vasilatos ja Wangsness 1981). V-ryhmällä rehuannos oli suurempi kuin R-ryhmällä, minkä vuoksi syöntikäyttäytymisessä oli eroja 23 päivää ennen odotettua poikimista. 14 päivää poikimisen jälkeen ryhmien välillä ei ollut eroja, koska lehmien dieetit olivat samanlaiset molemmilla ryhmillä. Syöntiaikojen ja -kertojen erojen häviäminen poikimisen jälkeen viittaa myös siihen, ettei ummessaolokauden ruokinnalla ollut pysyvää vaikutusta lehmien syöntikäyttäytymiseen. Syöntinopeuden on havaittu nousevan syöntimotivaation noustessa sekä eläimillä että ihmisillä, ja ruokinnan rajoittamisella voi olla pitkäkestoisia vaikutuksia syöntinopeuteen (Nielsen 1999, Nielsen ym. 2000, Munksgaard ym. 2005). Syöntinopeuden lisääntyminen ei ollut tilastollisesti merkitsevä tässä kokeessa.

Rehu on merkittävä veden lähde lypsylehmille (Murphy 1992). Rajoitetusti ruokitut lehmät joivat useammin 23 päivää ennen odotettua poikimista todennäköisesti siksi, että ne eivät saaneet rehusta yhtä paljon nestettä kuin vapaasti ruokitut lehmät. Toisaalta R-ryhmän lyhyempään keskimääräisen juontijakson kestoon saattoi olla syynä se, että rehun puutteessa niillä oli tarve muuhun suun alueen käyttäytymiseen, minkä takia ne kävivät vesikupilla useammin kuin V-ryhmä. Aikaisemmin on tutkittu, että rajoitetusti ruokitut lehmät voivat turhautuessaan suorittaa muita suun alueen toimintoja, kuten rehukupin ja itsensä nuolemista (Redbo ym. 1996). Vesikupilla käyminen voi myös olla tällaista toimintaa (Martiskainen ym. 2005). Juontikäyttäytymisessä ei ollut ryhmien välisiä eroja poikimisen jälkeen, koska dieetit muuttuivat ryhmillä samanlaisiksi. Märehtimisessä ei ollut eroja ryhmien välillä 23 päivää ennen poikimista, mihin voi olla syynä se, että rajoitetusti ruokitun ryhmän säilörehuannos oli riittävä stimuloimaan märehtimistä. Märehtimisaikaan vaikuttavat rehun määrä ja koostumus. Lisääntynyt rehunsyönti vähentää märehtimiseen suhteellisesti käytettyä aikaa. Märehtimisen aloitusta stimuloi karkearehun aiheuttama paine pötsissä (van Soest 1982). Ilmeisesti pienillä säilörehuannoksilla syönnin erot vaikuttivat selkeämmin märehtimiskäyttäytymiseen, koska tunnutuskauden aikana (10 päivää ennen poikimista) R-ryhmän lehmien märehtimisaika oli lyhyempi kuin V-ryhmän lehmien. R-ryhmän lehmien keskimääräinen säilörehun kuiva-aineen syönti oli tällöin $7 \mathrm{~kg} \mathrm{ka} / \mathrm{pv}$ ja V-ryhmän lehmien vastaavasti $8,8 \mathrm{~kg} \mathrm{ka} / \mathrm{pv}$. 


\section{Manipulointi-ja kehonhoitokäyttäytyminen}

23 päivää ennen odotettua poikimista V-ryhmän lehmät hoitivat itseään tai vieressä olevaa lehmää useammin (150 krt vs. 112 krt, p<0,10) kuin R-ryhmän lehmät. Hoitojaksojen kesto oli lyhyempi $(0,22$ $\mathrm{min} / \mathrm{krt}$ vs. 0,34 min/krt) V-ryhmän lehmillä $(\mathrm{p}<0,10)$. Rakenteiden manipuloinnissa ei ollut eroja ryhmien välillä. 14 päivää poikimisen jälkeen ryhmien välillä ei ollut eroja hoitokäyttäytymisessä. Ummessaolokaudella rajoitetusti ruokittu ryhmä käytti poikimisen jälkeen rakenteiden manipulointiin vähemmän aikaa (7,8 min vs. 11,3 min) kuin vapaasti ruokittu ryhmä $(\mathrm{p}<0,10)$.

Kehonhoidon tarkoituksena on pitää keho puhtaana, mutta se on myös osa naudan sosiaalista käyttäytymistä (Broom ja Fraser 2007). Hoitojaksot ajoittuvat yleensä syömisen yhteyteen (Lindström ja Redbo 2000, Mattiello ym. 2002), mikä saattaa selittää vapaasti ruokittujen lehmien taipumusta hoitaa itseään ja toisia lehmiä enemmän. Poikimisen jälkeen ryhmien välillä ei ollut eroja, koska ryhmien ruokinta oli tällöin samanlainen. Kun tarkastellaan kehonhoitojaksoja, on nähtävissä, että syöntiajan ja hoitokäyttäytymisen välillä oli käänteinen yhteys ennen ja jälkeen poikimisen. Hoitokäyttäytymisjaksojen määrä nousi molemmilla ryhmillä toisella havainnointikerralla, jolloin rehumäärä oli pienempi ja syöntiaika lyhyempi kuin ensimmäisellä havainnointikerralla. 14 päivää poikimisen jälkeen hoitojaksojen määrä laski verrattuna ennen poikimista tehtyihin havainnointeihin. Tällöin lehmät saivat rehua vapaasti ja syöntiaika pidentyi. Hoitokäyttäytymisen ja rehumäärän käänteinen yhteys viittaa siihen, että turhautuessaan rehumäärän niukkuuteen lehmät suorittavat sijaistoimintoja.

Naudat voivat lisätä rakenteiden manipulointia tai rakenteiden stereotyyppistä nuolemista ja puremista, jos niiden ympäristö on virikkeetön (Martiskainen ym. 2005). Rakenteiden manipulointia esiintyy kuitenkin jonkin verran kaikissa tuotantoympäristöissä, sillä se on naudalle luonnollista tutkiskelevaa käyttäytymistä. Todennäköisesti R-ryhmän lehmien rehumäärää ei rajoitettu niin paljon, että rakenteiden manipulointia olisi esiintynyt niillä merkittävästi enemmän kuin V-ryhmän lehmillä 23 päivää ennen poikimista. Rakenteiden manipulointi vähentyi selvästi kummallakin ryhmällä 14 päivää poikimisen jälkeen verrattuna 23 päivää ennen poikimista tehtyihin havaintoihin. Tämä viittaa siihen, että lisääntynyt rehusyönnin kesto vähentää muuta suun alueen manipulointikäyttäytymistä, mikä on todettu myös aikaisemmissa tutkimuksissa (Redbo ym. 1996, Redbo ja Nordblad 1997). Rakenteiden manipuloinnissa 14 päivää poikimisen jälkeen oli yllättäen suuntaa antava ero ryhmien välillä niin, että koeryhmällä manipulointikäyttäytymistä esiintyi vuorokaudessa keskimäärin kauemmin kuin vertailuryhmällä. On mahdollista, että rakenteiden manipuloinnin havainnoinnissa oli videoiden käsittelijästä johtuvaa virhettä, ja myös hajonta oli suurta lehmien välillä. Rakenteiden manipuloinnissa 14 päivää poikimisen jälkeen on paljon hajontaa lehmien välillä.

\section{Muu käyttäytyminen ja sonnan kortisolimetaboliittien pitoisuus}

Rajoitetusti ruokitut lehmät makasivat pää tuettuna pidempään kerrallaan kuin vapaasti ruokitut lehmät $(4,0 \mathrm{~min} / \mathrm{krt}$ vs. $2,5 \mathrm{~min} / \mathrm{krt}, \mathrm{p}<0,10) 23$ päivää ennen poikimista. Ero viittaa siihen, että Rryhmän lehmillä on ollut enemmän aikaa käytettävissään makaamiseen kuin V-ryhmän lehmillä. Ryhmien välillä ei ollut eroa seisomiskäyttäytymisessä. 14 päivää poikimisen jälkeen ryhmien välillä oli useita eroja niin pää tuettuna kuin pää koholla makaamisessakin. Ryhmien ruokinta oli keskenään samanlainen, joten eroja ei voida selittää ruokinnan erilaisuudella. Kummallakin ryhmällä makaamiseen käytetty aika väheni poikimisen jälkeen. Stereotyyppistä käyttäytymistä ei havaittu lainkaan suurimmalla osalla lehmistä. Niillä lehmillä, joilla näitä käyttäytymistoimintoja havaittiin, toimintakertoja oli useimmiten vain yksi. Tämä viittaa siihen, ettei ruokinnan rajoittaminen aiheuttanut eläimille voimakasta turhautumista.

Kortisolimetaboliittien pitoisuudessa ei ollut eroja ryhmien välillä 24 päivää ennen poikimista eikä 12 päivää poikimisen jälkeen. Sen sijaan 11 päivää ennen poikimista kortisolimetaboliittien pitoisuus sonnassa oli vapaasti ruokitulla ryhmällä suurempi kuin rajoitetusti ruokitulla ryhmällä (13, $3 \mathrm{ng} / \mathrm{g}$ vs. 11,5 ng/g, p<0,01). 12 päivää poikimisen jälkeen pitoisuus laski kummallakin ryhmällä noin puoleen aikaisemmin mitatuista pitoisuuksista. Vertailuryhmällä se oli $6,1 \mathrm{ng} / \mathrm{g} /$ tuoreessa sonnassa ja koeryhmällä $6,4 \mathrm{ng} / \mathrm{g} /$ tuoreessa sonnassa. Eroja ryhmien välillä ei kuitenkaan ollut. Kortisolin aineenvaihduntatuotteiden pitoisuus vaihteli eri tavalla eri ryhmillä vuorokauden aikana 
$(\mathrm{p}<0,05) 24$ päivää ennen poikimista. Ryhmien välillä ei ollut eroja kortisolimetaboliittien vuorokausivaihtelussa 11 päivää ennen poikimista tai 12 päivää poikimisen jälkeen. Kortisolin aineenvaihduntatuotteiden pitoisuus (keskimäärin 11,5 ng/g) 24 päivää ennen odotettua poikimista vastasi aikaisemmissa tutkimuksissa (Morrow ym. 2002) mitattuja perustason arvoja. Tästä voidaan päätellä, että ruokinnasta johtuva mahdollinen stressi ei näkynyt R-ryhmän kortisolimetaboliittipitoisuuksissa. 11 päivää ennen poikimista ilmennyt ero ryhmien välillä on voinut olla seurausta tunnutusruokinnasta, jolloin vertailuryhmän säilörehuannosta vähennettiin entisestään. Lisääntynyt rehumäärä voi olla syynä matalampiin pitoisuuksiin poikimisen jälkeen. Rehun syönti lähes kaksinkertaistui poikimisen jälkeen, jolloin myös sonnan määrä lisääntyi samassa suhteessa. Jos metaboliittien eritys pysyi samalla tasolla kuin ennen poikimista, niiden pitoisuus sonnan määrään nähden laski.

\section{Johtopäätökset}

Ummessaolokaudella rajoitetusti ruokitut lehmät käyttivät syömiseen vähemmän aikaa vuorokaudessa kuin vapaasti ruokitut lehmät. Myös syöntikertoja oli vähemmän. Rajoitetusti ruokittu ryhmä joi enemmän ja kävi vesikupilla useammin kuin vapaasti ruokittu ryhmä. Rajoitetusti ruokitut lehmät saivat säilörehusta vähemmän nestettä kuin vapaasti ruokitut, mikä selittää osaltaan juontikäyttäytymisen eroja. On myös mahdollista, että vesikupilla käyminen oli korvaavaa tekemistä seurauksena rehunpuutteeseen turhautumisesta. Ennen tunnutuksen alkamista karkearehun määrä oli ilmeisesti molemmilla ryhmillä riittävä ylläpitämään märehtimistä. Märehtimisaika lyheni tunnutusaikana erityisesti rajoitetusti ruokitulla ryhmällä, kun säilörehuannosta pienennettiin. Rajoitetusti ruokitut lehmät makasivat 23 päivää ennen poikimista pitempiä jaksoja rentoutuneemmassa tilassa, pää tuettuna kuin vapaasti ruokitut. Stereotyyppistä käyttäytymistoimintaa havaittiin vain muutamalla lehmällä kokeen aikana, mikä viittaa siihen, ettei ruokinnan rajoittaminen energian tarpeen mukaiseksi aiheuttanut eläimille voimakasta turhautumista.

Ruokintatasolla oli jonkin verran vaikutusta lehmien HPA-akselin toimintaan. Sonnan kortisolin aineenvaihduntatuotteiden pitoisuuksien vuorokautinen vaihtelu oli erilaista eri ryhmillä 24 päivää ennen poikimista. Tunnutusruokinnan aikana (11 päivää ennen poikimista) rajoitetusti ruokitun ryhmän kortisolimetaboliittipitoisudet olivat suuremmat kuin vapaasti ruokitun ryhmän. Pitoisuuksien väheneminen molemmilla ryhmillä poikimisen jälkeen saattaa selittyä rehun syönnin lisääntymisellä.

Tämän tutkimuksen perusteella ummessaolokauden rajoitettu ruokinta ei aiheuta merkittävää stereotyyppistä käyttäytymistä lypsylehmillä. Tutkimuksessa tuli kuitenkin esille joitakin viitteitä siitä, että rajoitettu ruokinta ummessaolokaudella voi aiheuttaa turhautumista niukan rehumäärän takia ja muutoksia syönti- ja juontikäyttäytymisessä. Lehmien kokonaisenergiansaantia voidaan kontrolloida rajoittamalla rehunsaantia tai muuttamalla dieetin koostumusta. Ummessaolokauden ruokinnassa tulisikin käyttää sellaista rehua, jonka energiapitoisuus on matalampi kuin lypsykauden rehuissa, mutta jonka syömiseen kuluisi paljon aikaa. Tämä voisi vähentää ummessa olevien lehmien toimettoman ajan osuutta vuorokaudessa ja sitä kautta turhautumista rehunpuutteeseen.

\section{Kirjallisuus}

Broom, D.M. 1991. Animal welfare: concepts and measurement. Journal of Animal Science 69: 41674175.

Broom, D.M. 2010. Animal welfare: an aspect of care, sustainability, and food quality required by the public. Journal of Veterinary Medical Education 37: 83-88.

Broom, D.M. \& Fraser, A.F. 2007. Domestic animal behaviour and welfare. 4. painos. Wallingford, USA: CABI. $423 \mathrm{~s}$.

Broom, D.M. \& Johnson, K.G. 1993. Stress and Animal Welfare. Alankomaat: Kluwer Academic Publishers. $207 \mathrm{~s}$.

Hofer, H. \& East, M.L. 1998. Biological conservation and stress. Advances in the Study of Behavior 27: 405-525. (Ref. Möstl, E. \& Palme, R. 2002) 
Hänninen, L. \& Pastell, M. 2009. CowLog: open source software for coding behaviors from digital video. Behavior Research Methods 41: 472-476.

Keyserlingk, M.A.G. \& Weary, D.M. 2010. Review: feeding behaviour of dairy cattle: measures and applications. Canadian Journal of Animal Science 90: 303-309.

Korte, S.M., Bouws, G.A.H. \& Bohus, B. 1993. Central actions of corticotropin-releasing hormone (CR-H) on behavioral, neuroendocrine and cardiovascular regulation: brain corticoid receptor involvement. Hormones and Behavior 27: 167-183.

Lindström, T. \& Redbo, I. 2000. Effect of feeding duration and rumen fill on behaviour in dairy cows. Applied Animal Behaviour Science 70: 83-97.

Martin, P. \& Bateson, P. 2007. Measuring behaviour: an introductory guide. Iso-Britannia:

Cambridge University Press. $171 \mathrm{~s}$.

Martiskainen, P., Mononen, J., Tuomisto, L. \& Tuovinen, V. 2005.

http://www.elke.fi/naudanetogrammi/ Viitattu 9.5.2011

Mason, G. \& Rushen, J. 2006. Stereotypic Animal Behavior: Fundamentals and Applications to Welfare. 2. painos. Wallingford, Iso-Britannia: CABI. $367 \mathrm{~s}$.

Mattiello, S., Canali, E., Ferrante, V., Caniatti, M., Gottardo, F., Gozzi, G., Andrighetto, I. \&

Verga, M. 2002. The provision of solid feeds to veal calves: II. Behavior, physiology and abomasal damage. Journal of Animal Science 80: 367-375.

Moberg, J.P. \& Mench, J.A. 2000. The biology of animal stress: basic principles and implications for animal welfare. Wallingford, USA: CABI. 384 s. (Ref. Morrow, C.J. ym. 2002)

Morrow, C.J., Kolver, E.S., Verkerk, G.A. \& Matthews, L.R. 2002. Fecal glucocorticoid metabolites as a measure of adrenal activity in dairy cattle. General and Comparative Endocrinology 126: 229-241.

MTT 2011. Rehutaulukot ja ruokintasuositukset. https://portal.mtt.fi/portal/page/portal/Rehutaulukot. Jokioinen: Maa- ja elintarviketalouden tutkimuskeskus. Viitattu 30.11.2011

Munksgaard, L., Jensen, M.B., Pedersen, L.J., Hansen, S.W. \& Matthews, L. 2005. Quantifying behavioural priorities-effects of time constraints on behaviour of dairy cows, Bos Taurus. Applied Animal Behaviour Science 92: 3-14.

Munksgaard, L., Herskin, M.S., Løvendahl, P. \& Andersen, J.B. 2006. Effects of nutrition on stress activity. Teoksessa: Sejrsen, K., Hvelplund, T. \& Nielsen, M.O. (toim.). Ruminant physiology. Wageningen, Alankomaat: Wageningen Academic Publishers. s. 511-521.

Murphy, M.R. 1992. Water metabolism of dairy cattle. Journal of Dairy Science 75: 326-333.

Möstl, E. \& Palme, R. 2002. Hormones as indicators of stress. Domestic Animal Endocrinology 23: 67-74.

Nielsen, B.L. 1999. On the interpretation of feeding behaviour measures and the use of feeding rate as an indicator of social constraint. Applied Animal Behaviour Science 63: 79-91. Nielsen, B.L, Veerkamp R.F. \& Lawrence, A.B. 2000. Effects of genotype, feed type and lactational stage on the time budget of dairy cows. Acta Agriculturae Scandinavica 50: 272-278.

Phillips, C. 2002. Cattle behaviour and welfare. 2. painos. Oxford, Iso-Britannia: Blackwell Science Ltd. $264 \mathrm{~s}$.

Redbo, I., Emanuelson, M., Lundberg, K. \& Oredsson, N. 1996. Feeding level and oral stereotypies in dairy cows. Animal Science 62: 199-206.

Redbo, I. \& Nordblad, A. 1997. Stereotypies in heifers are affected by feeding regime. Applied Animal Behaviour Science 53: 193-202.

van Soest, P. J. 1982. Nutritional ecology of the ruminant. 2. painos. USA: Cornell University Press. $476 \mathrm{~s}$.

Vasilatos, R. \& Wangsness, P.J. 1981. Diurnal variations in plasma insulin and growth hormone associated with two stages of lactation in high producing dairy cows. Endocrinology 108: 300-304. 